\title{
Obesitas Sebagai Faktor Risiko yang Paling Berpengaruh terhadap Kejadian Diabetes Mellitus Tipe 2 (Studi Kasus Kontrol)
}

\author{
Obesity as the Dominant Risk Factor Influence on the Incidence of Type 2 Diabetes Mellitus \\ (Case Control Study)
}

\author{
Riyanto $^{1, \bowtie}$, Yusro Hadi Maksum ${ }^{1}$ \\ ${ }^{1}$ Jurusan Kebidanan, Poltekkes Kemenkes Tanjungkarang, Indonesia \\ ${ }^{凶}$ Corresponding author: nsriyanto70@yahoo.com
}

\section{Kata kunci: \\ Obesitas faktor \\ dominan, \\ diabetes mellitus \\ tipe 2 kota Metro.}

Keyword:

Obesity is the dominant

factor,

diabetes mellitus type 2

Metro city.

\begin{abstract}
Abstrak
Latar belakang: Prevalensi Diabetes Mellitus yang tertinggi tahun 2007 di kota Metro dari 10 kabupaten/kota di provinsi Lampung berdasarkan diagnosis tenaga kesehatan. Tujuan: Penelitian ini bertujuan untuk mengetahui besar faktor-faktor resiko kejadian DM tipe 2. Metode: Penelitian ini menggunakan rancangan studi kasus kontrol yang dilakukan di 5 Puskesmas kota Metro. Populasi dalam penelitian ini adalah semua penduduk yang tinggal di kota Metro yang berkunjung ke Puskesmas. Jumlah sampel penelitian dengan perbandingan 1: 1 atau 101 kelompok kasus dan 101 kelompok kontrol yang diambil dengan teknik consecutive sampling. Pengumpulan data bersumber data primer menggunakan metode wawancara dan observasi. Analisis data menggunakan analisis multivariat dengan uji regresi logistik berganda (multiple regresi logistik). Hasil: Penelitian memperlihatkan hasil pemodelan multivariat akhir terjadinya DM tipe 2, terdapat 3 variabel yaitu variabel obesitas (ORadjusted =8,237; CI 95\%: 3,442-19,710), riwayat keturunan (ORadjusted $=7,322$; CI 95\%: 3,250-16,498) dan aktivitas olah raga (ORadjusted $=2,403$; CI 95\%: 0,980-5,892). Simpulan: Obesitas sebagai determinan paling berpengaruh (dominan) terhadap penyakit DM type 2 dengan besar risiko 8,2 kali dibandingkan orang yang mempunyai berat badan normal, setelah dikontrol oleh variabel riwayat keturunan dan aktivitas olah raga, serta jenis kelamin dan umur.. Penurunan dan pengendalaian DM tipe 2 yang utama adalah mengendalikan obesitas pada masyarakat dengan gaya hidup yang sehat.
\end{abstract}

\begin{abstract}
Background: The prevalence of Diabetes Mellitus in Metro city from 10 regencies / cities in Lampung province is based on the highest diagnosis of health workers. Purpose: This study aims to determine the risk factors for type 2 diabetes mellitus. Methods: This study used a case-control study design conducted at 5 Metro City Health Centers. The population in this study were all residents who lived in the city of Metro who visited the Puskesmas. The number of research samples with a ratio of 1: 1 or 101 case groups and 101 control groups were taken by consecutive sampling technique. Collecting data sourced from primary data using interview and observation methods. Data analysis used multivariate analysis with multiple logistic regression tests (multiple logistic regression). Results: The study showed the results of the final multivariate modeling of type $2 \mathrm{DM}$, there were 3 variables namely obesity variable (ORadjusted $=8.237 ; 95 \%$ CI: 3.442-19.710), hereditary history (ORadjusted $=7.322 ; 95 \% \mathrm{CI}:$ 3,250-16,498) and activity exercise (ORadjusted = 2,403; 95\% CI: 0,980-5,892). Conclusion: Obesity as the most influential (dominant) determinant of type 2 DM with a 8.2 times greater risk than people who have normal weight, after being controlled by hereditary history variables and sports activities, as well as gender and age. Decrease and control of type 2 DM is primarily to control obesity in people with a healthy lifestyle.
\end{abstract}

Copyright $\odot 2018$ Jurnal Kesehatan Metro Sai Wawai. All rights reserved. 


\section{Pendahuluan}

Tantangan global, regional, dan nasional adalah terjadinya tren dari tahun ke tahun peningkatan PTM yang menyebabkan transisi epidemiologi dari penyakit menular menjadi penyakit tidak menular semakin jelas (Kemenkes RI, 2012). Salah satu PTM tersebut adalah diabetes mellitus (DM), sebagai penyakit menahun yang akan diderita seumur hidup, berdampak kecacatan, memperpendek umur harapan hidup dan penyebab kematian utama penyakit endokrin (Pranoto, 2006) (Soegondo, S, 2009). Di seluruh dunia DM mempengaruhi sedikitnya 171 juta orang dan menyebabkan 3,2 juta kematian, setara dengan kematian HIV / AIDS, 6 kematian per menit dan 8700 kematian setiap hari (Biswas, 2006)

DM tipe 2 sebagai jenis yang paling banyak ditemukan, terdapat $90 \%$ lebih dari semua populasi diabetes dan selebihnya (10\%) adalah tipe lain (Suyono, 2009). Menurut Internasional Diabetes Federation (IDF) pada tahun 2005 di dunia terdapat 200 juta $(5,1 \%)$ orang dengan diabetes dan diduga 20 tahun kemudian, yaitu tahun 2025 akan meningkat menjadi 333 juta (6,3\%) (Depkes RI, 2008). WHO memprediksi bahwa Indonesia ditahun 2000 sebagai nomor empat di dunia terbanyak diabetisi $(8,4 \%)$, pada tahun 2030 akan tetap menjadi nomor 4 dengan 21,3\% juta diabetisi, setelah India 79,4 juta, China 42,3\% dan amerika serikat 30,3\% (Wild, 2004). Hal ini berarti terjadi peningkatan jumlah penyandang DM sehanyak 2-3 kali lipat atau sekitar 150\% setelah 3 dasa warsa. Sebaran peningkatan jumlah DM diperkirakan oleh WHO di negara maju pada tahun tersebut akan terdapat kenaikan 70\% dan 42\% di negaranegara berkembang (Narayan, 2011).

Prevalensi DM secara nasional dari hasil Riskesdas tahun 2007 ditemukan 5,7\%, terdiri atas 4,2\% atau $73,7 \%$ baru terdiagnosis saat penelitian dan sisanya $1,5 \%$ atau $26,3 \%$ sudah terdiagnosis sebelumnya (Badan Litbangkes Depkes RI, 2008). Menurut IDF pada tahun 2006 dibandingkan dengan prevalensi DM di Amerika Serikat (8,3\%) dan Cina (3,9\%), maka Indonesia sebagai negara berkembang berada diantaranya (Suyono, 2009). Sedangkan, prevalensi DM di provinsi Lampung 6,2\% berada di atas angka nasional $(5,7 \%)$ dan prevalensi tertinggi provinsi Kalimantan Barat (11,1\%) dan Maluku (11,1\%). Dari 10 kabupaten/kota di provinsi Lampung prevalensi DM berdasarkan diagnosis tenaga kesehatan tertinggi di kota Metro berjumlah 0,7\%, sedangkan berdasarkan diagnosis tenaga kesehatan atau mengalami gejala, prevalensi DM di kota Metro terbanyak kedua (0,7\%) setelah Bandar Lampung $(0,9 \%)$. Berdasarkan tipe daerah memperlihatkan prevalensi DM di provinsi Lampung lebih banyak di kota (70\%) dibandingkan di desa (30\%) (Badan Litbangkes Depkes RI, 2008). Adapun hasil prevalensi diabetes mellitus riset kesehatan dasar tahun tahun 2013 di provinsi Lampung turun menjadi 0,7\% (Badan Litbangkes Kemenkes RI, 2013). Terjadi tren peningkatan pada tiga tahun terakhir prevalensi diabetes mellitus di kota Metro, pada tahun 2010 sebanyak 1,6\% menjadi 1,8\% pada tahun 2011 dan tahun 2012 meningkat menjadi 1,9\% (Dinkes kota Metro, 2010-2012).

Peningkatan penyandang DM terutama DM tipe 2 di seluruh dunia termasuk di negara berkembang, terjadi karena perubahan gaya hidup yang salah dan menyebabkan obesitas (Suyono, S, 2009). Perubahan gaya hidup tersebut adalah aktivitas fisik kurang, merokok, diet tidak sehat dan penggunaan alkohol (Narayan, 2011) (Suyono, S, 2009). Hasil Riskesdas tahun 2007 secara nasional terdapat sejumlah 18,8\% responden dengan obesitas dan kurang aktivitas fisik pada kelompok umur $>10$ tahun terdapat 48,2\%. Prevalensi DM pada orang obesitas (IMT $\geq 27$ ) berjumlah 9,1\% dan obesitas sentral 9,7\% (Badan Litbangkes Depkes RI, 2008).

Kejadian DM tipe 2 dipengaruhi oleh multifaktor. Penelitian oleh (Irawan, 2010) di daerah urban Indonesia dengan menganalisis Data Riskesdas 2007 memperlihatkan bahwa obesitas merupakan faktor 
risiko yang dominan terjadinya DM tipe 2, setelah mengontrol tingkat pendidikan, pekerjaan dan umur. Hasil penelitian tersebut menunjukkan hasil odds ratio kegemukan sebesar 1,52 (OR = 1,52; 95\% CI: 1,27$1,82)$, odds ratio obesitas $2,40(\mathrm{OR}=2,40 ; 95 \% \mathrm{CI}: 1,80-3,19)$ dan odds ratio obesitas sentral $1,92(\mathrm{OR}=$ 1,92; 95\% CI: 1,62-2,26). Sebagian penelitian yang dilakukan di kota Depok oleh (Rahmawati, Setiarini, \& Sudikno, 2009) memperlihatkan faktor yang dominan terjadinya DM adalah faktor keturunan dengan odds ratio $6,628(\mathrm{OR}=6,628 ; 95 \% \mathrm{CI}: 2,061-21,317)$. Faktor resiko lain yang mempengaruhinya terjadinya $\mathrm{DM}$ adalah faktor sosiodemografi, antara lain umur, jenis kelamin, tingkat pendidikan dan pekerjaan.

Beberapa penelitian di atas memperlihatkan hasil yang berbeda faktor dominan terjadinya DM tipe 2. Oleh karena itu, penelitian ini bertujuan menganalisis faktor yang paling berpengaruh (dominan) kejadian DM tipe 2 di kota Metro, sehingga diperoleh jaring-jaring sebab akibat utama (cor problem) dari DM tipe 2 di kota Metro dengan analisis multivariat dan desain penelitian studi kasus kontrol.

\section{Metode}

Penelitian ini menggunakan rancangan studi kasus kontrol. Rancangan penelitian untuk mengetahui pengaruh faktor risiko pendidikan, pekerjaan, pendidikan, pekerjaan, status merokok, aktivitas olah raga, riwayat keturunan, obesitas dan hipertensi terhadap kejadian DM tipe 2. Kelompok kasus adalah penduduk kota Metro yang berkunjung ke Puskesmas di kota Metro yang didiagnosis penyakit DM tipe 2 oleh tenaga medis berdasarkan hasil pemeriksaan gula darah sewaktu $>200 \mathrm{mg} / \mathrm{dl}$. Sedangkan, kontrol adalah penduduk kota Metro yang tidak menderita DM pada saat yang sama yang berkunjung ke Puskesmas kota Mmetro yang terpilih dan memnuhi syarat penelitian. Penelitian dilaksanakan pada bulan November 2015 di wilayah Puskesmas kota Metro. Puskesmas kota Metro yang dipilih berdasarkan perwakilan kecamatan di kota Metro meliputi: Puskesmas Metro Pusat, Puskesmas Purwosari, Puskesmas Ganjar Agung, Puskesmas Tejoagung dan Puskesmas Yosomulyo.

Populasi penelitian ini adalah semua penduduk yang tinggal di kota Metro yang berkunjung ke Puskesmas Metro saat penelitian. Jumlah minimal sampel dihitung menggunakan rumus pengambilan sampel tidak berpadanan (Hosmer \& Lemeshow, 2000) berdasarkan penelitian terdahulu oleh (Soetirto, Roselinda, \& Suhardi, 2010) dengan P1=0,101, P2=0,23 dan OR=2,28 diperoleh jumlah sampel minimal 101 responden yang terdiri atas 101 kelompok kasus dan 101 kelompok kontrol yang diambil proporsional dari lima Puskesmas. Pengambilan sampel kelompok kasus dan kelompok kontrol dijodohkan (maching) dengan umur dan jenis kelamin. Sampel diretriksi dengn kriteria inklusi sampel penelitian adalah penduduk kota Metro yang berkunjung ke Puskesmas di kota Metro dengan penyakit DM tipe 2 pada periode 1 tahun terakhir berdasarkan hasil pemeriksaan gula darah sewaktu > $200 \mathrm{mg} / \mathrm{dl}$ dan pernyataan tenaga medis yang memeriksa atau mengkonsumsi obat diabetes, untuk kelompok kasus. Sedangkan, kelompok kontrol adalah penduduk kota Metro yang tidak menderita DM pada saat yang sama dan domisilinya tidak jauh (satu kelurahan) dengan kasus. Adapun kriteria eksklusi sampel penelitian adalah kelompok kasus sedang hamil. Sedangkan, kelompok kasus menderita DM tipe 1.

Pemilihan kelompok kasus dilakukan dengan cara memilih kasus dari kunjungan pasien di Balai Pengobatan Puskesmas di kota Metro yang didiagnosis penyakit DM tipe 2 yang memenuhi syarat penelitian. Sedangkan, pemilihan kelompok kontrol dilakukan setelah kelompok kasus diperoleh, kemudian memilih kelompok kontrol, yaitu pasien yang berkunjung ke Puskesmas di wilayah kota Metro; (2) memilih kelompok kontrol; dan (3) mencatat identitas kelompok kontrol.

Pengumpulan data terhadap masing-masing variabel penelitian dilakukan melalui wawancara. Wawancara menggunakan kuesioner terstruktur dilakukan kepada responden langsung untuk data variabel penelitian meliputi: riwayat keturunan DM, aktifitas olah raga, status merokok, pendidikan, pekerjaan, 
riwayat obesitas dan riwayat hipertensi. Selain itu, data umur dan jenis kelamin untuk penapisan. Pengumpulan data dibantu 5 Enumerator yang sebelumnya diberikan pelatihan untuk meminimalkan terjadinya bias. Analisis data dilakukan secara bertahap dimulai dari analisis univariat, kemudian analisis bivariat dan multivariat. Analisis multivariate menggunakan model faktor prediksi dengan menggunakan uji regresi logistik berganda (multiple regresi logistik) (Hosmer \& Lemeshow, 2000).

\section{Hasil}

\section{Karakteristik responden menurut kelompok kasus}

Hasil analisis berdasarkan karakteristik responden menunrut kelompok kasus memperlihatkan dari 101 kasus DM tipe 2 terdapat 84,2\% responden tidak bekerja, 39,6\% responden berpendidikan SMP ke bawah, $42,6 \%$ responden mengalami obesitas, 45,5\% responden dengan riwayat keturunan, 88,1\% responden kurang aktivitas olah raga, 6,9\% responden merokok, dan 32,7\% responden mengalami hipertensi.

\section{Hasil analisis bivariat}

Analisis bivariat memperlihatkan dari 7 (tujuh) variabel independen, terdapat 4 variabel yang berpengaruh signifikan dan masuk seleksi kandidat multivarait kejadian DM Tipe 2 di kota Metro, yaitu variabel obesitas (IMT), riwayat keturunan, aktivitas olah raga dan hipertensi (lihat tabel 1).

Tabel 1.

Hasil AnalisisBivariat Untuk Seleksi Kandidat Multivariat

\begin{tabular}{lcc}
\hline \multicolumn{1}{c}{ Variabel Independen } & OR $($ CI 95\%) & $\boldsymbol{p}$ value \\
\hline Perkerjaan & $0,849(0,485-1,487)$ & 0,568 \\
Pendidikan & $1,231(0,593-1,557)$ & 1,231 \\
Obesitas & $8,619(3,785-19,624)$ & $0,000^{*}$ \\
Riwayat keturunan & $7,611(3,554-16,297)$ & $0,000^{*}$ \\
Aktivitas olah raga & $2,440(1,149-5,182)$ & $0,029^{*}$ \\
Merokok & $1,179(0,382-3,639)$ & 1,000 \\
Hipertensi & $1,965(1,034-3,736)$ & $0,055^{*}$ \\
\hline
\end{tabular}

Keterangan : * signifikan dan masuk seleksi kandidat multivariat

\section{Hasil analisis multivariat}

\section{Seleksi kandidat multivariat}

Hasil uji bivariat yang menujukkan $p$ value $<0,25$ maka variabel tersebut dimasukkan sebagai kandidat model multivariat. Bila hasil uji bivariat menunjukkan $p$ value $>0,25$ namun secara substansi mempunyai kemaknaan penting, maka variabel tersebut akan dimasukkan dalam model multivariat. Hasil uji bivariat dari 7 variabel penelitian yang secara statistic mempunyai kemaknaan $(p=<0,25)$ terdapat 4 variabel, maka variabel tersebut memenuhi syarat dimasukkan kedalam pemodelan awal analisis multivariat. Variabel tersebut adalah obesitas, riwayat keturunan, aktivitas olah raga dan hipertensi (tabel 2).

\section{Pemodelan multivariat awal}

Analisis pemodelan multivariat awal memperlihatkan dari 4 variabel penelitian terdapat 2 variabel yang mempunyai nilai $p$ value $>0,05$. Sehingga, variabel tersebut harus di keluarkan dari pemodelan secara bertahap dimulai dari variabel yang $p$ valuenya terbesar dimulai dari variabel hipertensi (table 3 ). 
Tabel 2.

Hasil analisis bivariat untuk seleksi kandidat multivariat

\begin{tabular}{lc}
\hline \multicolumn{1}{c}{ Variabel Independen } & $\boldsymbol{p}$ value \\
\hline Obesitas menurut IMT & 0,000 \\
Riwayat keturunan & 0,000 \\
Aktivitas olah raga & 0,029 \\
Hipertensi & 0,055 \\
\hline
\end{tabular}

Tabel 3.

Hasil pemodelan multivariat awal faktor risiko kejadian DM tipe 2

\begin{tabular}{cccccc}
\hline Variabel & \multirow{2}{*}{$\boldsymbol{B}$} & \multirow{2}{*}{ Sig } & \multirow{2}{*}{ oRadjusted } & \multicolumn{2}{c}{ 95,0\% C.I.for EXP(B) } \\
\cline { 5 - 6 } & & 0,000 & 8,058 & 3,366 & 19,288 \\
Obesitas menurut (IMT) & 2,087 & 0,000 & 7,269 & 3,215 & 16,432 \\
Riwayat keturunan & 1,984 & 0,077 & 2,275 & 0,915 & 5,674 \\
Aktivitas olah raga & 0,824 & 0,156 & 1,720 & 0,812 & 3,643 \\
Hipertensi & 0,542 & 0,000 & 0,026 & & \\
Konstanta & 3,663 & $0,00 r$ & \\
\hline
\end{tabular}

\section{Pemodelan multivariat akhir}

Langkah berikutnya melakukan analisis untuk memperoleh pemodelan multivariat akhir terjadinya DM tipe 2. Pemodelan multivariat akhir dilakukan dengan mengeluarkan variabel yang mempunyai nilai $p$ value $>0,05$ secara bertahap dimulai dari variabel dengan $p$ value terbesar, yaitu dari variabel hipertensi dan seterusnya, sehingga variabel penelitian mempunyai nilai $p<0,05$ dengan hasil disajikan pada tabel 4 . Tabel 4 memperlihatkan hasil pemodelan multivariat akhir terjadinya DM tipe 2, terdapat 3 variabel yaitu variabel obesitas (ORadjusted =8,237; CI 95\%: 3,442-19,710), riwayat keturunan (ORadjusted =7,322; CI 95\%: 3,250-16,498) dan aktivitas olah raga (ORadjusted =2,403; CI 95\%: 0,980-5,892). Sedangkan, variabel hipertensi tidak masuk model $(\mathrm{p}=0,156>0,05)$.

Faktor obesitas merupakan determinan paling berpengaruh (dominan) seseorang dapat mengalami penyakit DM type 2 (ORadjusted 8,2), kemudian riwayat keturunan (ORadjusted 7,3) dan aktivitas olah raga (ORadjusted 2,4). Responden yang obesitas berisiko mengalami DM type 2 sebesar 8,2 kali dibandingkan orang yang mempunyai berat badan normal, setelah dikontrol oleh variabel riwayat keturunan dan aktivitas olah raga, serta jenis kelamin dan umur (dengan penjodohan kelompok kasus dan kontrol). Selain itu, dari pemodelan akhir dengan O (Obesitas sentral), RK (Riwayat keturunan) dan AOR (Aktivitas olah raga), maka diperoleh persamaan regresi logistik pemodelan multivariat akhir, yaitu Z (DM Type 2) $=3,298+2,109 \cdot \mathrm{O}+1,991 \cdot \mathrm{RK}+0,877 \cdot \mathrm{AOR}$.

Tabel 4.

Hasil pemodelan multivariat akhir faktor risiko kejadian DM tipe 2 di kota Metro

\begin{tabular}{lccccc}
\hline \multirow{2}{*}{ Variabel } & \multirow{2}{*}{$\boldsymbol{B}$} & \multirow{2}{*}{$\boldsymbol{S i g}$} & \multirow{2}{*}{$\boldsymbol{E x p}(\boldsymbol{B})$} & \multicolumn{2}{c}{$\mathbf{9 5 , 0 \%}$ C.I.for $\boldsymbol{E X P}(\boldsymbol{B})$} \\
\hline Obesitas & 2,109 & 0,000 & 8,237 & 3,442 & 19,710 \\
Riwayat keturunan & 1,991 & 0,000 & 7,322 & 3,250 & 16,498 \\
Aktivitas olah raga & 0,877 & 0,055 & 2,403 & 0,980 & 5,892 \\
\multicolumn{1}{c}{ Konstanta } & 3,298 & 0,000 & 0,026 & & \\
\hline
\end{tabular}

\section{Pembahasan}

\section{Obesitas, riwayat keturunan dan aktifitas olah raga dan dan kejadian DM tipe 2}

Kejadian DM tipe 2 dipengaruhi oleh multifaktor risiko. Penelitian ini bertujuan memperoleh faktor risiko/penyebab yang paling berpengaruh (dominan) terjadinya DM tipe 2. Hasil penelitian dari model 
multivariat akhir terjadinya DM tipe 2, terdapat 3 variabel, yaitu variabel obesitas (ORadjusted $=8,2$; CI 95\%: 3,4-19,7), riwayat keturunan (ORadjusted $=7,3$; CI 95\%: 3,2-16,4) dan aktivitas olah raga (ORadjusted $=2,4 ;$ CI $95 \%: 0,9-5,8)$.

Faktor obesitas merupakan determinan paling berpengaruh (dominan) seseorang dapat mengalami penyakit DM type 2 (ORadjusted 8,2), kemudian riwayat keturunan (ORadjusted 7,3) dan aktivitas olah raga (ORadjusted 2,4). Selain itu, dari pemodelan akhir dengan O (Obesitas sentral), RK (Riwayat keturunan) dan AOR (Aktivitas olah raga), maka diperoleh persamaan regresi logistik pemodelan multivariat akhir, yaitu $\mathrm{Z}$ (DM type 2$)=3,298+2,109 . \mathrm{O}+1,991 . \mathrm{RK}+$ 0,877.AOR Penelitian ini mendukung hasil penelitian yang dilakukan oleh (Irawan, 2010) terhadap data Riskesdas 2007 yang meneliti faktor risiko kejadian DM tipe 2 di daerah urban Indonesia memperoleh hasil faktor obesitas sebagai faktor paling berpenagruh, setelah mengontrol tingkat pendidikan, pekerjaan dan umur didapatkan OR sebesar 2,4 (OR=0,240; 95\% CI: 1,62-2,26).

Hasil analisis penelitian ini menunjukkan responden mengalami obesitas berisiko mengalami DM tipe 2 sebesar 8,2 kali dibandingkan orang yang mempunyai berat badan normal, setelah dikontrol (tanpa faktor risiko lain) antara lain variabel riwayat keturunan dan aktivitas olah raga, serta jenis kelamin dan umur (dengan penjodohan kelompok kasus dan kontrol) (ORadjusted =8,2; CI 95\%: 3,4-19,7).

Peningkatan penyandang DM terutama DM tipe 2 di seluruh dunia termasuk di negara berkembang, terjadi karena perubahan gaya hidup yang salah dan menyebabkan obesitas (Suyono, 2009). Perubahan gaya hidup tersebut diantaranya adalah aktivitas fisik kurang, selain merokok, diet tidak sehat dan penggunaan alkohol (Narayan, 2011) (Suyono, 2009). Hal lain yang dapat terjadi bahwa obesitas merupakan salah satu faktor yang melatar belakangi seseorang dengan riwayat keturunan DM untuk sampai dapat terkena efek DM. Selain itu, yang melatarbelakngi adalah, umur menua, infeksi virus, pola makan yang salah, minum obat-obatan yang bisa menaikkan kadar glukosa dalam darah, proses menua, stres, dan lain-lain (Waspadji, 2009). DM tipe 2 perlu upaya pencegahan dan pengendalian, diantaranya dari faktor obseitas. Upaya untuk menurunkan dan mengendalikan diabetes hendaknya dilakukan dengan memutus faktor resiko yang dapat dirubah, terutama prilaku yang dapat mencegah obesitas, seperti mengatur asupan makanan atau diet yang sehat, melakukan aktifitas fisik yang cukup dan tidak merokok, terlebih bagi orang yang telah berusia lebih dari 40 tahun.

Faktor keturunn merupakan faktor risiko terjadinya diabetes. DM merupakan penyakit keturunan, bila orang tua menderita DM maka anaknya akan berisiko untuk menderita juga. Jika ada anggota keluarga yang DM, maka seseorang akan berpeluang mendapatkan DM dua kali lebih tinggi dibandingkan orang yang tidak mempunyai keluarga dengan DM (Suyono, 2009).

Hasil penelitian lain dari pemodelan multivariat akhir terjadinya DM tipe 2 memperlihatkan riwayat keturunan (ORadjusted =7,322; CI 95\%: 3,250-16,498) dan aktivitas olah raga (ORadjusted $=2,403$; CI 95\%: 0,980-5,892) menjadi faktor risiko terjadinya DM tipe 2. Faktor riwayat keturunan berisiko mengalami DM type 2 sebesar 7,3 kali dibandingkan orang yang tidak mempunyai dan aktivitas olah raga kurang berisiko mengalami DM type 2 sebesar 2,4 kali dibandingkan orang yang melakukan olah raga aktif.

Penelitian ini sama dengan hasil penelitian-penelitian sebelumnya. Penelitian oleh (Kekenusa, Ratag, \& Wuwungan, 2013) pada pasien rawat jalan di Poliklinik Penyakit Dalam BLU RSUP Prof. Dr. RD Kandou Manado orang yang memiliki riwayat keluarga menderita DM 5 kali lebih berisiko menderita DM Tipe 2 dibandingkan dengan orang yang tidak memiliki riwayat keluarga menderita DM (nilai $\mathrm{p}=0,000$; $\mathrm{OR}=4,7)$. Riwayat keturunan menjadi prediktor yang kuat terhadap kejadian DM bersamaan dengan faktor risiko lain. Hal ini sesuai dengan pernyataan (Suyono, 2009) untuk sampai terkena efek DM ada beberapa 
faktor lain yang melatarbelakangi, yaitu umur menua. Selain itu, seperti infeksi virus, kegemukan, pola makan yang salah, minum obat-obatan yang bisa menaikkan kadar glukosa dalam darah, proses menua, stres, dan lain-lain (Suyono, 2009).

Upaya untuk menurunkan dan mengendalikan peningkatan diabetes pada sesorang mempunyai riwayat keturunan, ketika bertambah usia hendaknya sering melakukan pemeriksaan GDS secara rutin minimal 1 tahun sekali, lebih-lebih bila dirasakan adanya 3 tanda klasik, yaitu polipagi, polidipsi dan poli uri. Selain itu, pentingnya memperhatikan gaya hidup yang lain yang menjadi faktor risiko terjadinya diabetes mellitus.

Obesitas sebagai faktor risiko DM tipe 2 dari hasil analisis juga dikontrol oleh variabel kurang beraktivitas olah raga. Hasil pemodelan akhir multivariate didapatkan persamaan $\mathrm{Z}($ DM Type 2) = 3,298 + 2,109 (obesitas) $+1,991$ (keturunan) + 0,877 (aktivitas olah raga), maka variabel obesitas merupakan determinan paling dominan terhadap terjadinya DM type 2 di Kota Metro (p value 0,000 dan OR 8,237).

Hasil penelitian ini sejalan dengan penelitian yang dilakukan oleh (Ansari \& Okosun, 2009) yang melakukan penelitian menggunakan Survei kesehatan nasional Pakistan memperoleh adanya hubungan antara bersepeda dengan penurunan risiko kejadian diabetes mellitus tipe 2 ( $\mathrm{RR}=0.82$; 95\% CI 0.68-1.00, $\mathrm{P}=0.048$ ). Disamping itu, penelitian oleh (Rahajeng, 2007) juga rnenyebutkan bahwa orang dengan aktivitas fisik tinggi ( $\geq 120$ menit/hari) sebagai protektif 0,56 kali (HR:0,56; 95\% CI 0,32-0,99; p value $=0,005)$ terhadap kejadian diabetes mellitus tipe 2 dibandingkan dengan orang yang beraktivitas fisik rendah.

Aktivitas jasmani seperti olah raga merupakan faktor risiko lain yang berhubungan dengan kejadian DM tipe 2. Menurut (Kriska, 2003) bahwa aktivitas fisik memainkan peranan yang significant dalam mencegah kejadian diabetes melitus tipe 2 melalui penurunan berat badan dan komposisi tubuh. selain itu, dengan rneningkatkan aktivitas fisik, dapat membantu menormalkan kadar glukosa dalam darah, dan meningkatkan kerja insurin sehingga mencegah terjadinya diabetes melitus tipe 2. Kurangnya akivitas fisik menyebabkan zat makanan yang masuk kedalam tubuh akan diolah, tetapi kemudian hanya akan disimpan dalam tubuh dalam bentuk jaringan lemak. Untuk itu, aktifitas jasmani sangat dianjurkan untuk mengurangi kejadian DM tipe 2. Caranya melakukan latihan jasmani secara teratur (3-4 kali dalam seminggu) selama kurang tebih 30 menit, yang sifatnya sesuai CRIPE (continuous, rhythmical, interval, progressive, endurance traning). Sedapat mungkin mencapai zona sasaran 75-80\% denyut nadi maksimal (220-umur), disesuikan dengan kemampuan dan kondisi penyakit penyerta jika ada (Waspadji, 2009). Latihan jasmani selain untuk kebugaran juga dapat untuk menurunkan berat badan dan memperbaiki sensitivitas insulin sehingga akan memperbaiki kendali glukosa darah.

\section{Simpulan dan Saran}

Hasil penelitian menyimpulkan faktor risko yang berhubungan dengan kejadian DM tipe 2 di kota Metro adalah variabel obesitas, riwayat keturunan, aktivitas olah raga dan hipertensi. Faktor risiko yang paling dominan terhadap kejadian DM tipe 2 di kota Metro adalah obesitas, kemudian riwayat keturunan dan aktivitas olah raga. Orang yang mengalami obesitas berdasarkan IMT berisiko mengalami DM type 2 sebesar 8,2 kali dibandingkan orang yang mempunyai berat badan normal, setelah dikontrol oleh variabel riwayat keturunan dan aktivitas olah raga.

Upaya-upaya yang perlu dilakukan untuk mencegah dan mengendalikan peningkatan DM tipe 2 adalah melakukan upaya-upaya program penurunan dan pengendalian obesitas sebagai faktor resiko DM tipe 2 sebagai skala prioritas dan meningkatkan program prilaku atau gaya hidup sehat di tingkatan rumah tangga, seperti tidak merokok, melakukan aktifitas fisik yang cukup, seperti olah raga minimal 3-4 x/minggu 
selama minimal 30 menit baik di Posyandu Lansia di tiap kelurahan maupun di lingkungan rumahnya masing-masing dan gaya hidup lainnya. Selain itu, melakukan sekrening terhadap penyakit diabetes bagi yang mempunyai faktor resiko terjadi DM, seperti riwayat keturunan setiap tahun dan melakukan skrining setiap 3 tahun sekali bagi yang mempunyai faktor resiko terjadi DM untuk mendeteksi secara dini kasuskasus DM yang sering terdiagnosis terlambat, yaitu saat masyarakat merasakan keluhan dan datang ke fasilitas kesehatan, bahkan datang dengan komplikasi.

\section{Referensi}

Ansari, R. M., \& Okosun, I. S. (2009). Clinical study,effect of physical activity and obesity on type 2 diabetes in a middle-aged population. Journal of Environmental and Public Health, Vol 5.

Badan Litbangkes Depkes RI. (2008). Riset Kesehatan Dasar Tahun 2007. Jakarta: Depkes RI.

Biswas, A. (2006). Prevention of type 2 diabetes-life style modification with diet and psysical activity vs psysicala activity. Korolinska Institutes.

Depkes RI. (2008). Pedoman teknis penemuan dan tata laksana penyakit DM. Jakarta: Depkes RI.

Hosmer, D., \& Lemeshow, S. (2000). Applied logistic regression. Second Edition. Second edition. Canada: Jhon Wiley and Sons.

Irawan, D. (2010). prevalensi dan faktor resiko kejadian dm tipe 2 di daerah urban Indonesia. Thesis. FKM Universitas Indonesia. Depok: Analisis Data Sekunder Riskesdas 2007.

Kekenusa, J. S., Ratag, B. T., \& Wuwungan, G. (2013). Analisis hubungan antara umur dan riwayat keluarga menderita dmdengan kejadian penyakit dm tipe 2 pada pasien rawat jalandi poliklinik penyakit dalam $B L$ DR. R.D Kandau Manado. Manado: FKM Universitas Sam Ratulangi Manado. Retrieved Mei 8, 2013, from http://fkm.unsrat.ac.id

Kemenkes RI. (2012). Profil kesehatan Indonesia tahun 2012. Jakarta: Kemenkes RI.

Badan Litbangkes Kemenkes RI. (2013). Riset Kesehatan Dasar Tahun 2013. Jakarta: Badan Litbangkes Kemenkes RI.

Kriska, E.A. (2003). Physical activity, obesity, and the incidence of type 2 diabetes in a high-risk population American. Johns Hopkins Bloomberg School of Public Health . USA: American Journal Of epidemiology.

Luciana, E. (2008). Hubungan aktivitas fisik dengan kendali gula darah pada penyandang DM tipe 2 di RS Husada Jakarta. Thesis. Depok: FKM Universitas Indonesia.

Narayan, E. A. (2011). Diabetes public health pinted. Oxford University Press. United States of America: on acid-free Paper.

Pranoto. (2006). Konsensus pengelolaan dan pencegahan DM tipe 2 di Indonesia. Retrieved Mei 8, 2013, from http://penelitian.unair.ac.id/artikel

Rachmah, W. (2006). Diabetes meliitus pada usia lanjut dalam buku ajar ilmu penyakit dalam.Volume III (3 ed.). Jakarta: Fakultas Kedokteran Universitas Indonesia.

Rahajeng. (2007). Risiko diet terhadap peningkatan kejadian diabetes melitus tipe 2 pada kasus toleransi glukosa terganggu. Jurnal Ekologi. 6(1), 527-39.

Rahmawati, Setiarini, A., \& Sudikno. (2009). Pengaruh status gizi terhadap kejadian hiperglikemia pada pegawai negeri sipil: studi kasus kota depok tahun 2009. Jurnal Gizi Indonesia. 32(1): 63-65.

Soetirto, F., Roselinda, \& Suhardi. (2010). Diabetes mellitus dengan obesitas berdasarkan IMT dan lingkar pinggang data Riskesdas 2017. Buletin Penelitian dan Kesehatan. 38(1), 36-47. 
Soegondo, S. (2009). Prinsip penanganan diabetes, insulin dan obat hipoglikemik oral dalam penatalaksanaan DM terpadu. Vol 2 (7 ed). Jakarta: Balai Penerbit Fakultas Kedokteran Universitas Indonesia.

Suyono, S. (2009). Kecenderungan peningkatan jumlah penyandang diabetes dalam penatalaksanaan DM terpadu. Vol 2 (7 ed.). Jakarta: Balai Penerbit Fakultas Kedokteran Universitas Indonesia.

Suyono, S. (2009). Patofifiologi diabetes mellitus dalam penatalaksanaan DM terpadu. Volume 2 (7 ed.). Jakarta: Balai Penerbit Fakultas Kedokteran Universitas Indonesia.

Waspadji, S. (2009). Diabetes mellitus penyakit kronik dan pencegahannya dalam penatalaksanaan DM terpadu. Volume 2 (7 ed.). Jakarta: Balai Penerbit FKUI.

Wild, S. E. (2004). Estimates for the year 2000 and projections for 2030. Retrieved Juni 2, 2013. DOI: https://doi.org/10.2337/diacare.27.5.1047 